\title{
EMERGING AND RE-EMERGING DISEASE
}

\author{
Elavarasi.R, ArunaDevi. M, Ruma Shanthini.K, Guna.S*
}

\begin{abstract}
The spectrum of infectious disease is changing rapidly in conjunction with dramatic societal and environmental changes. Worldwide, explosive population growth with expanding poverty and urban migration is occurring; international travel and commerce are increasing; and technology is rapidly changing, all of which affect the risk of exposure to infectious agents. Infectious diseases are emerging, re-emerging, and increasing in the United States, taking a toll in both morbidity and mortality. A major cause of the emergence of new diseases is environmental change (for example, human encroachment into wilderness areas and increased human traffic through previously isolated areas). The re-emergence of some diseases can be explained by evolution of the infectious agent (for example, mutations in bacterial genes that confer resistance to antibiotics used to treat the diseases). In partnership with representatives from health departments, other federal agencies, medical and public health professional associations, and international organizations has developed a strategic plan to address emerging infectious disease threats. The plan contains four goals that emphasize surveillance, applied research, prevention and control, and public health infrastructure. To ensure sustainability, plan implementation will be approached in stages, as a long-term endeavor with emphasis on extramural programs. As health-care reform proceeds priority should be given to strengthening partnerships between health-care providers, microbiologists, and public health professionals to detect and control emerging and re-emerging infectious diseases.
\end{abstract}

Key words: emerging, environment, infectious disease

\section{Introduction}

Infectious diseases are dominant public health problem even in the $21^{\text {st }}$ Century and world's leading cause of death for children and adolescents. WHO estimates $25 \%$ of the total 57 million annual deaths that occur worldwide are caused by microbes and this proportion is significantly higher in the developing country ${ }^{1}$. In 1997, WHO formulated world health day theme focusing on these issue as "Emerging Infectious Diseases- Global Alert: Global Response"

The burden of morbidity and mortality associated with infectious diseases falls most heavily on people in developing countries, and particularly on infants and children (about three million children die each year from malaria and diarrheal diseases alone $)^{4}$.
Emerging \& Re-emerging zoonotic diseases, food borne and waterborne diseases $\&$ diseases caused by multi resistant organism constitute the major threats in India. In the first half of 2014, Ebola caused over 200 deaths in West Africa and over 500 people contracted Middle East Respiratory Syndrome (MERS). ${ }^{2}$ There were more than 145 fatal cases of MERS.

There has been a remarkable progress in the prevention, control and even eradication of infectious diseases (Smallpox) with improved hygiene \& development of antimicrobials and vaccines. However, tragically, with optimism came a false sense of security, which has helped many diseases to spread with alarming speed. ${ }^{2}$

* R.Elavarasi, ArunaDevi.M Ruma Shanthini.K, Guna.S Asst.Professors., Dept. of Community Health Nursing, KGNC, Puducherry 607402, India. 


\section{Emerging Diseases:}

The term "emerging infectious diseases" refers to diseases of infectious origin whose incidence in humans either has increased within the past two decades or threatens to increase in the near future.

They are caused by a newly evolved organism or an organism that has undergone a mutation resulting in a new strain; they may result from the introduction of the organism to humans from another species; or they may result from dissemination of the organism from its existence in a small, circumscribed range of infection (which may not even be apparent or cause only slight illness) to susceptible populations. ${ }^{6}$

These include new, previously undefined diseases as well as old diseases with new features. These new features may include the introduction of a disease to a new location or a new population (e.g. it may present in youth where previously it was only seen in the elderly); new clinical features, including resistance to available treatments; or a rapid increase in the incidence and spread of the disease. ${ }^{14}$

\section{Examples of Emerging Infectious Diseases:}

In the past 20 years, at least 30 new diseases have emerged to threaten the health of hundreds of millions of people.

\begin{tabular}{|c|l|l|}
\hline $\begin{array}{c}\text { Year } \\
\text { identified }\end{array}$ & \multicolumn{1}{|c|}{ Agent } & \multicolumn{1}{|c|}{ Disease } \\
\hline $\mathbf{1 9 7 3}$ & Rota virus & Infantile diarrhea \\
\hline $\mathbf{1 9 7 5}$ & Parvovirus & $\begin{array}{l}\text { Aplastic crisis in } \\
\text { chronic hemolytic } \\
\text { anemia }\end{array}$ \\
\hline $\mathbf{1 9 7 6}$ & cryptosporidium & $\begin{array}{l}\text { Acute and chronic } \\
\text { diarrhea }\end{array}$ \\
\hline $\mathbf{1 9 7 7}$ & Ebola virus & $\begin{array}{l}\text { Ebola hemorragic } \\
\text { fever }\end{array}$ \\
\hline $\mathbf{1 9 7 7}$ & $\begin{array}{l}\text { Legionella } \\
\text { pneumophillia }\end{array}$ & $\begin{array}{l}\text { Legionnaries' } \\
\text { disease }\end{array}$ \\
\hline
\end{tabular}

\begin{tabular}{|c|c|c|}
\hline 1977 & Hantaan virus & $\begin{array}{l}\text { Hemorrhagic } \\
\text { fever with renal } \\
\text { syndrome(HFRS) }\end{array}$ \\
\hline 1980 & HTLV-1 & $\begin{array}{l}\text { T-cell lymphoma- } \\
\text { luekemia }\end{array}$ \\
\hline 1982 & E coli O157:H7 & HUS \\
\hline 1982 & $\begin{array}{l}\text { Borrelia } \\
\text { burgdoferi }\end{array}$ & Lyme disease \\
\hline 1982 & HTLV-2 & $\begin{array}{l}\text { Hairy cell } \\
\text { leukemia }\end{array}$ \\
\hline 1983 & HIV & AIDS \\
\hline 1983 & H.Pylori & $\begin{array}{l}\text { Peptic ulcer } \\
\text { disease }\end{array}$ \\
\hline 1986 & BSE agent & $\begin{array}{l}\text { Bovine spongiform } \\
\text { encephalopathy in } \\
\text { cattle(Mad cow } \\
\text { disease) }\end{array}$ \\
\hline 1988 & HHV- 6 & Exanthemsubitum \\
\hline 1988 & Hepatitis $\mathrm{E}$ virus & $\begin{array}{l}\text { Enterically } \\
\text { transmitted } \\
\text { non-A, non-B } \\
\text { hepatitis }\end{array}$ \\
\hline 1989 & Hepatitis $C$ virus & $\begin{array}{l}\text { Parentally } \\
\text { transmitted } \\
\text { non-A, non-B } \\
\text { hepatitis }\end{array}$ \\
\hline 1992 & $\begin{array}{l}\text { Vibrio cholera O } \\
139\end{array}$ & $\begin{array}{l}\text { New strain } \\
\text { associated with } \\
\text { epidemic cholera }\end{array}$ \\
\hline 1992 & $\begin{array}{l}\text { Bartonella } \\
\text { henselae }\end{array}$ & $\begin{array}{l}\text { Cat scratch } \\
\text { diseases }\end{array}$ \\
\hline 1995 & HHV-8 & $\begin{array}{l}\text { Association with } \\
\text { kaposi's sarcoma in } \\
\text { AIDS patients }\end{array}$ \\
\hline 1996 & Prion & CJD \\
\hline 1997 & $\begin{array}{l}\text { Influenza A } \\
\text { virus(H5N1) }\end{array}$ & Avian fly(bird flu) \\
\hline
\end{tabular}




\begin{tabular}{|l|l|l|}
\hline $\mathbf{2 0 0 3}$ & Corona virus & SARS \\
\hline $\mathbf{2 0 0 9}$ & H1N1 & $\begin{array}{l}\text { Pandemic } \\
\text { A(H1N1) 2009 } \\
\text { influenza }\end{array}$ \\
\hline
\end{tabular}

The emerging infectious diseases account for 26 per cent of annual deaths worldwide. Nearly 30 per cent of 1.49 billion disability-adjusted life years (DALYs) are lost every year to diseases of infectious origin. ${ }^{4}$

\section{Re-Emerging Disease:}

"Re-emerging infectious diseases are those diseases that once were major health problems globally or in a particular country and then declined dramatically, but are again becoming health problems for a significant proportion of the population" ${ }^{2}$

It often appear in epidemic proportions E.g.: TB, Cholera, Dengue, Malaria, H1N1 influenza, Ebola ${ }^{2}$

Re-emerging infectious diseases may occur because of the development of resistance to antimicrobial agents (as with gonorrhea), breakdown in public health measures (as with tuberculosis), and other reasons. Also included under the umbrella of emerging infectious diseases are agents that already existed and were widespread in humans but are newly recognized (e.g., herpes virus 6, now known to cause roseola) and association of an infectious agent with a chronic illness (e.g., Helicobacter pylori and peptic ulcer disease). ${ }^{15}$

The re-emergence of some diseases can be explained by the failure to immunize enough individuals, which results in a greater proportion of susceptible individuals in a population and an increased reservoir of the infectious agent. Increases in the number of individuals with compromised immune systems (due to the stress of famine, war, crowding, or disease) also explain increases in the incidence of emerging and re-emerging infectious diseases. ${ }^{18}$

The disease in question involves all the major modes of transmission i.e. spread either from person to person, by insects or animals or through contaminated water or food. ${ }^{22}$

\begin{tabular}{|c|c|c|}
\hline Disease & Infectious Agent & $\begin{array}{l}\text { Contributing } \\
\text { Factors }\end{array}$ \\
\hline Chikungunya & Chikungunya virus & $\begin{array}{l}\text { viral genome } \\
\text { mutation } \\
\text { enabled } \\
\text { infection of } \\
\text { new mosquito } \\
\text { vectors and } \\
\text { expanded } \\
\text { transmission }\end{array}$ \\
\hline Cholera & $\begin{array}{l}\text { Vibrio cholera } 0139 \\
\text { (bacterium) }\end{array}$ & $\begin{array}{l}\text { evolution of } \\
\text { new strain } \\
\text { of bacteria } \\
\text { combining } \\
\text { increased } \\
\text { virulence and } \\
\text { long-term } \\
\text { survival in the } \\
\text { environment }\end{array}$ \\
\hline Cryptosporidiosis & $\begin{array}{l}\text { Cryptosporidium } \\
\text { parvum(protozoan) }\end{array}$ & $\begin{array}{l}\text { inadequate } \\
\text { control in } \\
\text { water supply; } \\
\text { international } \\
\text { travel; increased } \\
\text { use of child-care } \\
\text { facilities }\end{array}$ \\
\hline Dengue Fever & Dengue Virus & $\begin{array}{l}\text { urbanization, } \\
\text { international } \\
\text { travel, and } \\
\text { inadequate } \\
\text { vector-control } \\
\text { measures }\end{array}$ \\
\hline Diphtheria & $\begin{array}{l}\text { Corynebacterium } \\
\text { diptheriae(bacterium) }\end{array}$ & $\begin{array}{l}\text { interruption of } \\
\text { immunization } \\
\text { program due } \\
\text { to political } \\
\text { changes }\end{array}$ \\
\hline $\mathrm{H} 5 \mathrm{~N} 1$ influenza & $\begin{array}{l}\text { influenza } \mathrm{H} 5 \mathrm{~N} 1 \\
\text { virus }\end{array}$ & $\begin{array}{l}\text { living close to } \\
\text { H5N1-infected } \\
\text { poultry }\end{array}$ \\
\hline Malaria & $\begin{array}{l}\text { Plasmodium } \\
\text { species (protozoan) }\end{array}$ & $\begin{array}{l}\text { drug resistance; } \\
\text { favorable } \\
\text { conditions for } \\
\text { mosquito vector }\end{array}$ \\
\hline
\end{tabular}




\begin{tabular}{|c|c|c|}
\hline $\begin{array}{l}\text { Meningitis, } \\
\text { Necrotizing } \\
\text { Fasciitis (Flesh- } \\
\text { Eating Disease), } \\
\text { Toxic-Shock } \\
\text { Syndrome, And } \\
\text { Other Diseases }\end{array}$ & $\begin{array}{l}\text { Group A } \\
\text { Streptococcus } \\
\text { (bacterium) }\end{array}$ & uncertain \\
\hline $\begin{array}{l}\text { pertussis } \\
\text { (whooping } \\
\text { cough) }\end{array}$ & $\begin{array}{l}\text { Bordetella } \\
\text { pertussis } \\
\text { (bacterium) }\end{array}$ & $\begin{array}{l}\text { refusal to } \\
\text { vaccinate based } \\
\text { on fears the } \\
\text { vaccine is not } \\
\text { safe; other } \\
\text { possible factors: } \\
\text { decreased } \\
\text { vaccine efficacy } \\
\text { or waning } \\
\text { immunity } \\
\text { among } \\
\text { vaccinated } \\
\text { adults }\end{array}$ \\
\hline $\begin{array}{l}\text { Polio (Infant } \\
\text { Paralysis) }\end{array}$ & Poliovirus & - \\
\hline Rabies & Rabies Virus & $\begin{array}{l}\text { breakdown in } \\
\text { public health } \\
\text { measures; } \\
\text { changes in land } \\
\text { use; travel }\end{array}$ \\
\hline $\begin{array}{l}\text { Rift Valley } \\
\text { Fever (RVF) }\end{array}$ & RVF Virus & - \\
\hline $\begin{array}{l}\text { Rubeola } \\
\text { (Measles) }\end{array}$ & Measles Virus & $\begin{array}{l}\text { failure to } \\
\text { vaccinate; } \\
\text { failure to } \\
\text { receive second } \\
\text { dose of vaccine }\end{array}$ \\
\hline Schistosomiasis & $\begin{array}{l}\text { Schistosoma } \\
\text { Species (Helminth) }\end{array}$ & $\begin{array}{l}\text { dam } \\
\text { construction; } \\
\text { ecological } \\
\text { changes } \\
\text { favoring snail } \\
\text { host }\end{array}$ \\
\hline Trypanosomiasis & $\begin{array}{l}\text { Trypanosomabrucei } \\
\text { (Protozoan) }\end{array}$ & $\begin{array}{l}\text { human } \\
\text { population } \\
\text { movements into } \\
\text { endemic areas } \\
\text { due to political } \\
\text { conflict; } \\
\text { diagnosis is } \\
\text { very difficult, } \\
\text { and current } \\
\text { treatments } \\
\text { have severe } \\
\text { secondary } \\
\text { effects }\end{array}$ \\
\hline
\end{tabular}

\begin{tabular}{|l|l|l|}
\hline Tuberculosis & $\begin{array}{l}\text { Mycobacterium } \\
\text { Tuberculosis } \\
\text { (Bacterium) }\end{array}$ & $\begin{array}{l}\text { antibiotic-resistant } \\
\text { pathogens; } \\
\text { immunocompromised } \\
\text { populations } \\
\text { (malnourished, HIV- } \\
\text { infected, poverty } \\
\text {-stricken) }\end{array}$ \\
\hline West Nile & West Nile Virus & $\begin{array}{l}\text { complex } \\
\text { interactions } \\
\text { between the } \\
\text { virus, birds and } \\
\text { other animals, } \\
\text { mosquitoes, } \\
\text { and the } \\
\text { environment; } \\
\text { emergence in } \\
\text { U.S. and other } \\
\text { regions likely } \\
\text { due to global } \\
\text { travel }\end{array}$ \\
\hline yellow fever & yellow fever virus & $\begin{array}{l}\text { insecticide } \\
\text { resistance; } \\
\text { urbanization; } \\
\text { civil strife }\end{array}$ \\
\hline & & \\
& & \\
& & \\
& & \\
& &
\end{tabular}

\section{Factors in Emerging and Re-emerging Disease:}

Factors that influence the emergence or re-emergence of infectious diseases include social and behavioral changes, climate changes, environmental alteration, political upheaval, migration and transport, natural disasters, travel, demographic shifts, the erosion of public health infrastructure decreasing surveillance, prevention and control, decline in experts in areas of infectious diseases, economics, and health care advances and technology $\mathrm{y}^{20}$

The other factors also responsible for emergence and re-emergence of infectious diseases are:

- Unplanned and under-planned urbanization

- overcrowding and rapid population growth

- Poor sanitation

- Inadequate public health infrastructure

- Resistance to antibiotics

- Increased exposure of humans to disease vectors and reservoirs of infection in nature

- Rapid and intense international travel

- Practice of modern medicine and relaxation in immunization practices

- Deforestation

- Failure to control carriers or breakdown in water and sanitation systems

- Changes in genetic makeup of the pathogen

- High risk human behavior

- Channeling of funds to other problems ${ }^{7}$ 


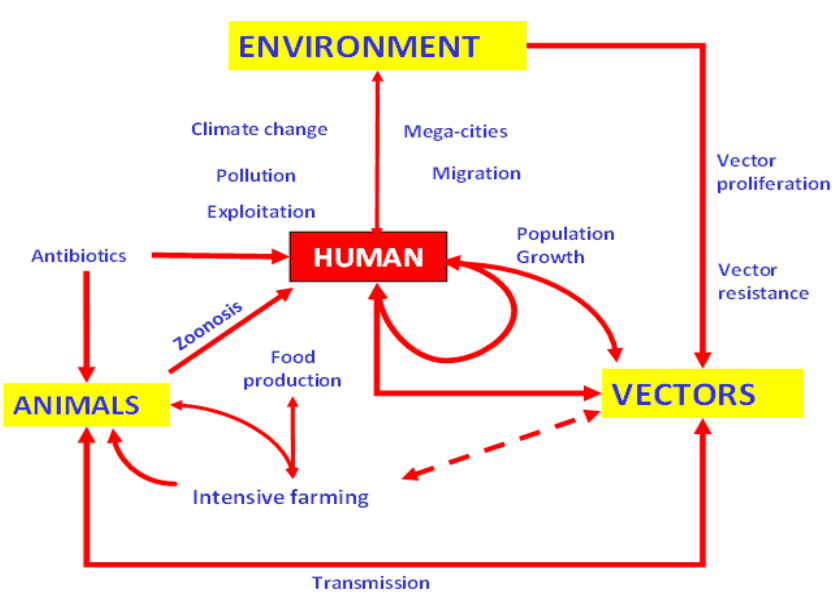

Global Initiative to Emerging Infectious Diseases:

\section{"Emerging and re-emerging infections reflect the constant struggle of microorganisms to survive"}

- Establishment of the Division of Emerging and other Communicable Diseases Surveillance and Control (EMC), by WHO (1995) ${ }^{9}$

- Strengthen national and international capacity in the surveillance and control of communicable diseases, including those that represent new, emerging and re-emerging public health problems, for which it ensures a timely and effective response ${ }^{8}$.

\section{Role of WHO:}

When a significant public health event takes place, WHO's comprehensive global alert and response system ensures that information is available and response operations are coordinated effectively ${ }^{21}$.

The system includes the following functions:

- Event-based surveillance, multi-hazard rapid risk assessment and event-based risk communications;

- Critical information and communications platforms for decision support; and

- Operations and logistics platforms for any WHO response to international public health risks ${ }^{21}$.

The World Health Organization, as one of the partners in this global effort, is strengthening global monitoring systems to serve as part of the overall detection system.

- In addition to partnership in global monitoring, WHO is working in countries to strengthen national disease detection and response through improved surveillance systems, and specialized training in epidemic preparedness and response.

- A final role of WHO in this partnership is to help ensure a coordinated global response to infectious diseases of international importance, often with the technical expertise of the WHO Collaborating Centres or other centres of excellence ${ }^{9}$.

\section{WHO collaborating centres:}

The first global monitoring system is that of the WHO Collaborating Centres, specialized Laboratories and institutions with expertise in infectious disease diagnosis and epidemiology.

- Not able to fully respond to global needs.

- Failed to keep up with changes in technology and were unable to provide the diagnostic support necessary to confirm the etiology of disease outbreaks.

- Not enough Collaborating Centres in developing countries to ensure regional selfsufficiency ${ }^{10}$.

\section{International Health Regulations (IHR):}

The International Health Regulations, or IHR (2005), represent an agreement between 196 countries including all WHO Member States to work together for global health security. ${ }^{21}$ The IHR help countries to prevent, detect, inform about and respond to public health events in facilitated. ${ }^{23}$

Three diseases are covered by the IHR - cholera, plague and yellow fever.

Through International Health Regulations, countries have agreed to build their capacities to detect, assess and report public health events. WHO plays the coordinating role in IHR and, together with its partners, helps countries to build capacities. It also includes specific measures at ports, airports and ground crossings to limit the spread of health risks to neighboring countries, and to prevent unwarranted travel and trade restrictions so that traffic and trade disruption is kept to a minimum. ${ }^{21}$ 


\section{CDC's Plan to Prevent Emerging Infectious Diseases:}

CDC will implement the plan in coordination with:

- State and local health departments (for surveillance)

- Academic centers and other federal agencies (for research)

- Health-care providers and organizations (for the development and dissemination of guidelines)

- International organizations (for outbreak responses overseas) $)^{11}$.

\section{Goals of CDC Plan:}

1. Surveillance and Response

2. Applied research

3. Infrastructure and Training

4. Prevention and control

\section{Surveillance and response:}

\section{Objectives}

- Strengthen infectious disease surveillance and response.

- Improve methods for gathering and evaluating surveillance data.

- Ensure the use of surveillance data to improve public health practice and medical treatment.

- Strengthen global capacity to monitor and respond to emerging infectious diseases. ${ }^{19}$

\section{Applied Research:}

Research is essential in efforts to understand, prevent, control, and respond to new and reemerging infectious diseases.

\section{Objectives}

- Develop, evaluate, and disseminate tools for identifying and understanding emerging infectious diseases.

- Identify the behaviors, environments, and host factors that put persons at increased risk for infectious diseases and their sequelae.

- Conduct research to develop and evaluate prevention and control strategies in the target areas. ${ }^{19}$

\section{Infrastucture and Training:}

\section{Objectives}

- Enhance epidemiologic and laboratory capacity.

- Improve CDC's ability to communicate electronically with state and local health departments, health-care professionals, and others.

- Enhance the nation's capacity to respond to complex infectious disease threats internationally, including outbreaks that may result from bioterrorism.

- Provide training opportunities in infectious disease epidemiology and diagnosis throughout the world $^{19}$

\section{Prevention and Control: Emerging Diseases \\ Objectives}

- Implement, support, and evaluate programs for the prevention and control of emerging infectious diseases.

- Develop, evaluate, and promote strategies to help health-care providers and other person's behaviors that facilitate disease transmission.

- Support and promote disease control and prevention internationally. ${ }^{20}$

\section{Target Areas}

- Antimicrobial resistance

- Foodborne and waterborne diseases

- Vector borne and zoonotic diseases

- Diseases transmitted through blood transfusions or blood products

- Chronic diseases caused by infectious agents

- Vaccine development and use

- Diseases of persons with impaired host defenses

- Diseases of pregnant women and newborns

- Diseases of travelers, immigrants, and refugees. ${ }^{20,22}$

\section{Prevention and control: Re emerging diseases}

- Early diagnosis and prompt treatment

- Vector control measures \&Prevention of epidemics, for malaria

- DOTS - for tuberculosis

- Research initiatives for treatment regimens and improved diagnostics, drugs and vaccines

- Strengthening epidemiological surveillance and drug-resistance surveillance mechanisms and procedures with appropriate laboratory 
support for early detection, confirmation and communication. ${ }^{12,22}$

\section{Community Health Nurse in Action:}

Community health nurse plays an important role in the prevention of emerging and re-emerging diseases and in the care of persons and families who have such diseases, it include,

1. Support, interpret, and disseminate the recommendations made by leading agencies.

2. Collaborate with other professions and policymaking groups in mutual support, endorsement, and evaluation of global strategies to prevent or reduce the threat of emerging microbial diseases.

3. Communicate with other nursing groups and recommend that they develop and disseminate to their own constituencies polices and standards to prevent the spread of emerging infections.

4. Identify mechanisms to promote appropriate prescriptions and use of anti-microbial agents.

5. Address strategies to enhance host resistance and immune competence

6. Take leadership in major initiatives to focus on preventive strategies.

7. Serve as a clear voice among policy makers for the support of public health, advocating support for public education, public health infrastructure and policies that protect the environment and promote ecological balance. ${ }^{16}$

\section{Nurses may act to prevent or intervene include the following:}

- Educate clients about risks and personal hygiene, which can include guarding against tick exposure; cooking meat thoroughly and eating thoroughly cooked meat; using safer sex techniques; washing one's hands after using the toilet, changing diapers, or exposure to fecal matter; and appropriate use of antibiotics to decrease inappropriate use of over-the-counter drugs and inappropriate requests for antibiotics from a provider.

- Use of infection control procedures; it is important that nurses have the ability to institute appropriate controls and to educate patients, visitors, family, and personnel about infection control and appropriate hand washing.
- Maintain awareness of unusual disease clusters, outbreaks, or illnesses, and be especially alert for unexplained deaths in young people.

- Institute or participate in immunization programs for adults and children, educate patients about the importance of immunization, and facilitate access to and availability of immunizations for those who need it.

- Use techniques to enhance client adherence to medication regimens to prevent treatment failure and development of microbial resistance.

- Participate in environmental cleanliness programs in the community and in the institution; this can encompass such items as adequate ventilation, air pollution, and basic public health measures such as safe water, elimination of places where birds roost and sources of standing water, and rodent control.

- Examine prescribing practices to ensure appropriate use of appropriate antibiotics.

- Be an advocate for clients about environment.

- Obtain thorough patient histories, including an assessment of travel history, recreational activities, and potential

- Exposures in the workplace, home, and community; for example manner in which workplace clothing in certain environments is handled can be important in transmitting infections and toxins to the home.

- Assess diet practices (for example, the use of unpasteurized milk) and teach clients about proper nutrition and food handling.

- Promote breast-feeding in countries in which there is a high risk of contamination of milk or infant formula.

- Train local people in health education and practices with use of culturally acceptable and locally accessible material and practices. ${ }^{17}$

\section{Role of research in prevention of emerging and re-emerging diseases:}

- Reestablish extramural program to support emerging infectious disease prevention and control activities

- Initiate prevention effectiveness studies to assess impact of food preparation guidelines.

- To develop a comprehensive computerized infectious disease database.

- Provide more funds to the health care professionals on researches based on emerging diseases. 
- To receive support from national research agencies on control of vector, and environmental factors that lead to infectious disease emergence.

- Increase research on surveillance and control; costs and benefits of prevention, control and treatment; diagnostic tests.

- Based on the research evidences increased priority of personal and community health practices relevant to disease transmission

- Promote in nursing education and curricula a population-based, epidemiologic, system approach for nursing practice and research. ${ }^{16}$

\section{Conclusion}

For a country of size and population of India, the emerging infections remain a real challenge. A meaningful response must approach the problem at the systems level. A comprehensive national strategy on infectious diseases addressing the challenges of emerging and re-emerging infections cutting across all relevant sectors, both governmental and nongovernmental, should be in place.

Identification of national centre of excellence and their capacity building is of critical importance. These centres of excellence should be encouraged to develop networking and partnerships between public health organizations to improve their individual scientific capacity, share best practices and expand collective knowledge base. Concerted efforts are also needed to develop advanced counter measures such as surveillance tools, diagnostic tests, vaccines and therapeutics through basic, translational and applied research. Sensitive rapid response mechanisms at various levels of health service are the cornerstone to detect public health threats and respond quickly enough to protect valuable human lives. National commitment and comprehensive efforts are necessary at all levels of health services in order to meet the threat of emerging and re-emerging infections.

\section{References:}

1. Altizer, S., et al. (2013) Climate Change and Infectious Diseases: From Evidence to a Predictive Framework (abstract) http://www.sciencemag.org/content/341/6145/514.abstract

2. Institute of Medicine. Emerging infections: microbial threats to health in the United States.Washington, DC: National Academy Press, 1992

3. CDC. Adoption of hospital policies for prevention of perinatal group B streptococcal disease -- United States, 1997. MMWR 1998;47:665-70.
4. Fauci AS. Infectious diseases: considerations for the $21 \mathrm{st}$ century. Clin Infect Dis 2001; $32: 675-85$

5. Claire V. Broome, Emerging Infectious Diseases, Centers for Disease Control and Prevention, Atlanta, GA, USA, Vol. 4, No. 3, July-September 1998;358-59.

6. Bhatia R, Narain JP, Plianbangchang S. Emerging infectious diseases in East and South-East Asia. In: Detels R, Sullivan SG, Tan CC, editors. Public health in East and South-east Asia. Berkeley, USA: University of California Press; 2012.p. 43-78

7. Morse, S.S. 1995. Factors in the emergence of infectious diseases. Emerging Infectious Diseases [Serial online], 1(1). Available http://www.cdc.gov/ncidod/EID/index.htm. June 1999;

8. WHO (1997), World Health Day Report 1997.

9. WHO (1996), The World Health Report 1996.

10. WHO (1999), Removing Obstacles to Healthy Development, WHO Report on Infectious diseases.

11. Park K . Textbook of Preventive and Social Medicine. 22ndt ed. Jabalpur: Bhanot; 2013.310-13.

12. Morbidity and Mortality weekly report (MMWR), Centers for Disease Control and Prevention (CDC) September 11, 1998 / Vol. 47 / No. RR-15.

13. Kenrad E N, Carolyn M W, Neil M H, Graham. Infectious Disease Epidemiology. Maryland: AN Aspen; 2001. p 301-48. URL available from, http://www.ias.ac.in/jbioscii. (03.05.2013)

14. Morse SS. Factors in the emergence of infectious diseases. Emerging Infect Dis 1995; 1 ( 1 ):7-15.

15. Morse SS. Examining the origins of emerging viruses. In: Morse SS, editor. Emerging viruses. New York: Oxford University Press, 1993: 10-28.

16. Felissa.LC, Elaine L, Emerging Infectious Disease: Nursing Reponses; 1996, Nursing Outlook, 44(4), pg.no. 164-168.

17. 17. Pope AM, Snyder MA, Mood LH, editors. Nursing, health and the environment. Institute of Medicine, Washington, DC: National Academy Press, 1995.

18. Joseph D et.al, Emerging and Re-emerging Infectious Diseases; 2012, pg.no.3-5

19. Centers for Disease Control. Addressing emerging infectious disease threats: a prevention strategy for the United States (executive summary). MMWR 1994:43;1-18. Report No.:RR-5.

20. Dash AP, Bhatia R, Sunyoto T \& Mourya DT, Emerging and Re-emerging arboviral Diseases in Southeast Asia; J Vector Borne Dis 50, June 2013, pp.77-84.

21. World Health Organization. strengthening health security by implementing the international health regulations (2005) available at http://www.who.int/ihr/alert_and_response/en/

22. Goel N, Gurpeet H \& Swami H, How to deal with Emerging and Re-Emerging infectious diseases globally. The Internet Journal of Biological Anthropology. 2006. 1(1), pp.no.14-18.

23. World Health Organization. Alert, response, and capacity building under the International Health Regulations (IHR), $2^{\text {nd }} \mathrm{ed} ; 2$ 2008. available at: http://www.who.int/ihr/ publications/9789241596664/en/ 